Article

\title{
Long-term (35 Years) Rainy and Dry Season Characterization in Semiarid Northeastern Brazil
}

\author{
J. Sparacino ${ }^{1,2}$ (D), D.S. Argibay ${ }^{1,2}$ (D), G. Espindola ${ }^{1}$ \\ ${ }^{I}$ Núcleo de Referência em Ciências Ambientais do Trópico Ecotonal do Nordeste, Universidade \\ Federal do Piaui, Teresina, PI, Brasil. \\ ${ }^{2}$ Centro De Ecología y Recursos Naturales Renovables, Universidad Nacional de Córdoba, \\ Córdoba, Argentina.
}

Received: 27 October 2020 - Accepted: 19 March 2021

\begin{abstract}
Uncertainties in the timing and quality of rainy season are a threat for food and water security, and also in terms of fire vulnerability. Then, understanding features associated to rainfall allows a climate characterization useful for climate and fire risk management. We used rainfall data series (1983-2018) from 15 meteorological stations to characterize the greatest conservation area of Brazilian-unique seasonally dry tropical forest Caatinga (northeastern Brazil). Accumulated anomalies in daily series were used to determine onset and end of rainy seasons. We also determined seasonal and annual rainfall (quality) and rain rate, and performed a dry season sub-classification. Results showed greater variability for end dates as compared to onset dates for rainy season. Droughts in the region are becoming more severe. We found a significant decreasing tendency of $7 \mathrm{~mm} /$ year on annual rainfall, of $0.3 \mathrm{~mm} /$ day per decade on rain rate, and an increase of 12 days per decade on consecutive dry days. Dry season length presented a 14-year periodicity and is related with previous but uncorrelated from posterior rainy season length. The complexity of the rainfall patterns is evidenced by the weak correlation we found between the amount of rainfall and the rainy season length.
\end{abstract}

Keywords: climate variability, Caatinga, drought, fire vulnerability, Serra da Capivara National Park, Serra das Confusões National Park.

\section{Caracterização de Longo Prazo (35 Anos) das Estações Secas e Chuvosas no Semiárido do Nordeste do Brasil}

\begin{abstract}
Resumo
As incertezas no momento e na qualidade da estação chuvosa representam uma ameaça para a seguridade hídrica e alimentar, e também enquanto à vulnerabilidade ao fogo. Logo, entender os atributos associados às chuvas facilita a caracterização climática, necessária para o manejo do risco climático e do fogo. Utilizou-se séries pluviométricas (19832018) de 15 estações meteorológicas para caracterizar a maior área de conservação da floresta seca tropical sazonal pertencente unicamente ao Brasil, a Caatinga (Nordeste do Brasil). Foram utilizadas anomalias acumuladas em séries diárias para determinar o início e o final das estações chuvosas. Também foi determinada a chuva sazonal e anual (qualidade) e a taxa de chuva, e foi executada uma subclassificação da estação seca. Os resultados mostraram maior variabilidade para as datas de final em comparação com as de início da estação chuvosa. As secas na região estão ficando mais severas. Foi encontrada uma tendência decrescente significativa de $7 \mathrm{~mm} /$ ano da chuva anual e de $0,3 \mathrm{~mm} /$ dia por década na taxa de chuva, e um incremento de 12 dias por década dos dias secos consecutivos. A duração da estação seca apresentou uma periodicidade de 14 dias e está relacionada com o comprimento da estação chuvosa anterior mas não com a posterior. A complexidade dos padrões da chuva é evidenciada pela fraca correlação encontrada entre a quantidade de chuva e a duração da estação chuvosa.
\end{abstract}

Palavras-chave: variabilidade climática, Caatinga, seca, vulnerabilidade ao fogo, Parque Nacional da Serra da Capivara, Parque Nacional da Serra das Confusões.

Corresponding author: javiersparacino@gmail.com. 


\section{Introduction}

Semiarid environments are mainly characterized by alternating rainy and dry seasons (seasonality), rainfall concentration, periods of pronounced water shortage, and the occurrence of fires (Allen et al., 2017; Archibald et al., 2013; Prăvălie, 2016). Uncertainties in the timing and quality of rainy season represent a threat for food and water security (Gutiérrez et al., 2014), and also in terms of fire vulnerability (Holden et al., 2018). Also, climate variability at various time scales affects social and natural systems enhancing the socio-economic vulnerability of the population of semiarid regions of the world (IPCC, 2014; Marengo and Bernasconi, 2015; Vieira et al., 2015), and intersecting other aspects of inequality such as ethnicity, gender, and state policies (Yadav and Lal, 2018). Moreover, extreme events are expected to become more frequent and changes in rainfall regimes in semiarid regions are predicted as a consequence of climate change (Allen et al., 2017; IPCC, 2012).

Three of the most important quantities determining rainy season are onset, end, and rain rate (Liebmann et al., 2007). These quantities are important from meteorological and societal perspectives. From the meteorological viewpoint, onset and end of rainy season represent sudden changes in a tropical atmospheric heat source, and its rate determines the magnitude of that heat source (Correia Filho et al., 2019; Horel et al., 1989; Liebmann et al., 2007). On the other hand, from a societal viewpoint, dates of onset and end of rainy season, as well as the amount of accumulated seasonal rainfall are of importance to agriculture, particularly in rainfed family agriculture which is still a broad practice in many semiarid regions of the world (Rockström et al., 2010; Sietz et al., 2006). Moreover, for agricultural and ecological studies, characterization of the dry season can be very relevant. Timing, length and severity of dry season affect forest biomass growth, the risk of fires, forest recuperation after disturbances (including fire), atmospheric carbon sequestration, and also the sustainability of agricultural settlements (Sombroek, 2001).

The climatology of rainy season onset and end has been studied using several methodologies. Kousky (1988) used outgoing long-wave radiation as a proxy for rainfall to analyze rainy season in South America, while Horel et al. (1989) used it for studying rainy season in the Amazon basin and tropical South America. Instead, groundbased rainfall observations with pentad averages was used by Marengo et al. (2001) to study rainy season onset and end in the Amazon basin. Liebmann and Marengo (2001) and Liebmann et al. (2007) introduced a methodology, also derived from ground-based rainfall observations, that defines rainy season onset and end by analyzing accumulated daily anomalies in rainfall. In this way, it is not necessary to choose any threshold in order to identify the rainy season. Since it was proposed, this methodology has been widespread used (Camberlin et al., 2009; Coelho et al., 2016; Debortoli et al., 2017; Marjuki et al., 2016).

Dry seasons are the time periods between those of rainy seasons, and are completely determined by the dates of onset and end of two consecutive rainy seasons. The delayed arrival of rains or the anticipated end of rainy seasons can lead to rainfall values below the annual mean leading to a meteorological drought (Van Loon et al., 2016). Thus, dry season characterization can also be useful to understand and analyse droughts. Consecutive dry days (CDD), the maximum number of consecutive days in a year with daily rainfall under some threshold, has been used in the literature as a measure for drought (Frich et al., 2002; IPCC, 2012; Marengo et al., 2017).

In northeastern Brazil (NEB) multiple droughts have been documented since the sixteenth century (Marengo et al., 2017, 2018). Impacts of droughts are still important in recent years, a multi-annual drought extended over the period 2012-2017 in NEB, considered the worst of recent decades, was devastating to some agricultural, livestock, and industrial producers, causing lack of drinking water in residential wells, extremely low reservoir levels and serious restrictions to pasture availability due to the late arrival of rain, even triggering social unrest in some districts in rural areas (Barbosa et al., 2019; Gutiérrez et al., 2014; Marengo et al., 2017, 2018; Martins et al., 2018).

Interannual variation in rainfall over NEB is related to large-scale atmospheric and oceanic characteristics. There is a relationship between rainfall anomalies in the region and El Niño and the Southern Oscillation (ENSO) phenomenon (Clarke, 2008). The low phase of the Southern Oscillation (El Niño) is associated to reduced rainfall in NEB, while its high phase is associated to enhanced rainfall (La Niña) (Marengo et al., 2018). Interannual variation in rainfall is also related to sea-surface temperature (SST) anomalies in the Atlantic and to the position of Inter Tropical Convergence Zone (ITCZ) (Hastenrath, 2012; Rodrigues and McPhaden, 2014). A northward displacement of the ITCZ leads to drought in NEB (Hastenrath, 2012; Kane, 1997).

Climate characterization is also useful for understanding fire regimes, since climate, together with topography, soil and vegetation combine to create unique fire dynamics (Bond and Keeley, 2005; Cochrane, 2003). Moreover, many threats to biodiversity which have anthropogenic origin, like climate change, agricultural expansion, logging, overgrazing, and land-use change interact with and alter fire regimes (Shlisky et al., 2009). In particular, climate change alters the key factors that control fire: temperature, precipitation, humidity, wind, ignition, biomass, dead organic matter, vegetation species composition and structure, and soil moisture (Shlisky et al., 2007). In turn, rainfall indirectly controls fire activity by the production and, thus, by the availability of 
fuels (Mayr et al., 2018), and also by determining the fuel moisture that limits the extension of fires (Argañaraz et al., 2018). Therefore, both the amount and distribution of rainfall through the year shapes fire regimes.

In this context, we focused on a region of semiarid NEB that includes two fully protected areas: Serra das Confusões and Serra da Capivara National Parks, that together constitute the greatest conservation area of the Brazilian-unique biome Caatinga (seasonal dry tropical forest) and its ecotone with Cerrado (savanna). The aim of this work was to characterize the interannual variability of onset, end and length of the rainy and dry seasons in this region. Also, to identify long-term trends and to study the relations between rainy season features (onset, end and length) with seasonal rainfall. Moreover, we aimed at characterizing the severity of dry season and its long-term trend. A spatial daily average of rainfall over the stations within the study area was constructed to guarantee data availability for a long-term characterization (35 years), since available data from the stations within the region is incomplete. Besides contributing to the understanding of interannual variability of rainfall in this climate and socio- economic vulnerable region of NEB, we also aimed to discuss its implications to the local environment and fire regimes.

\section{Material and Methods}

\subsection{Study area}

The study was conducted in the southern part of the Brazilian state of Piauí, a semiarid region located between the sediment basin of Parnaíba river and the peripheral depression of the São Francisco river (Lemos and Rodal, 2002). The landscape is a mosaic of cultural uses and Caatinga vegetation that is adapted to the semiarid climate (Olmos, 1992; Prado, 2003; Santos et al., 2014). It presents in the southwestern region an ecotonal area between Caatinga and Cerrado with predominance of deciduous forest and arboreal Caatinga (Dinerstein et al., 2017).

A square of $2.5^{\circ}$ side that includes Serra da Capivara and Serra das Confusões National Parks was used to define our study area and all meteorological stations within that square were considered (see Fig. 1).

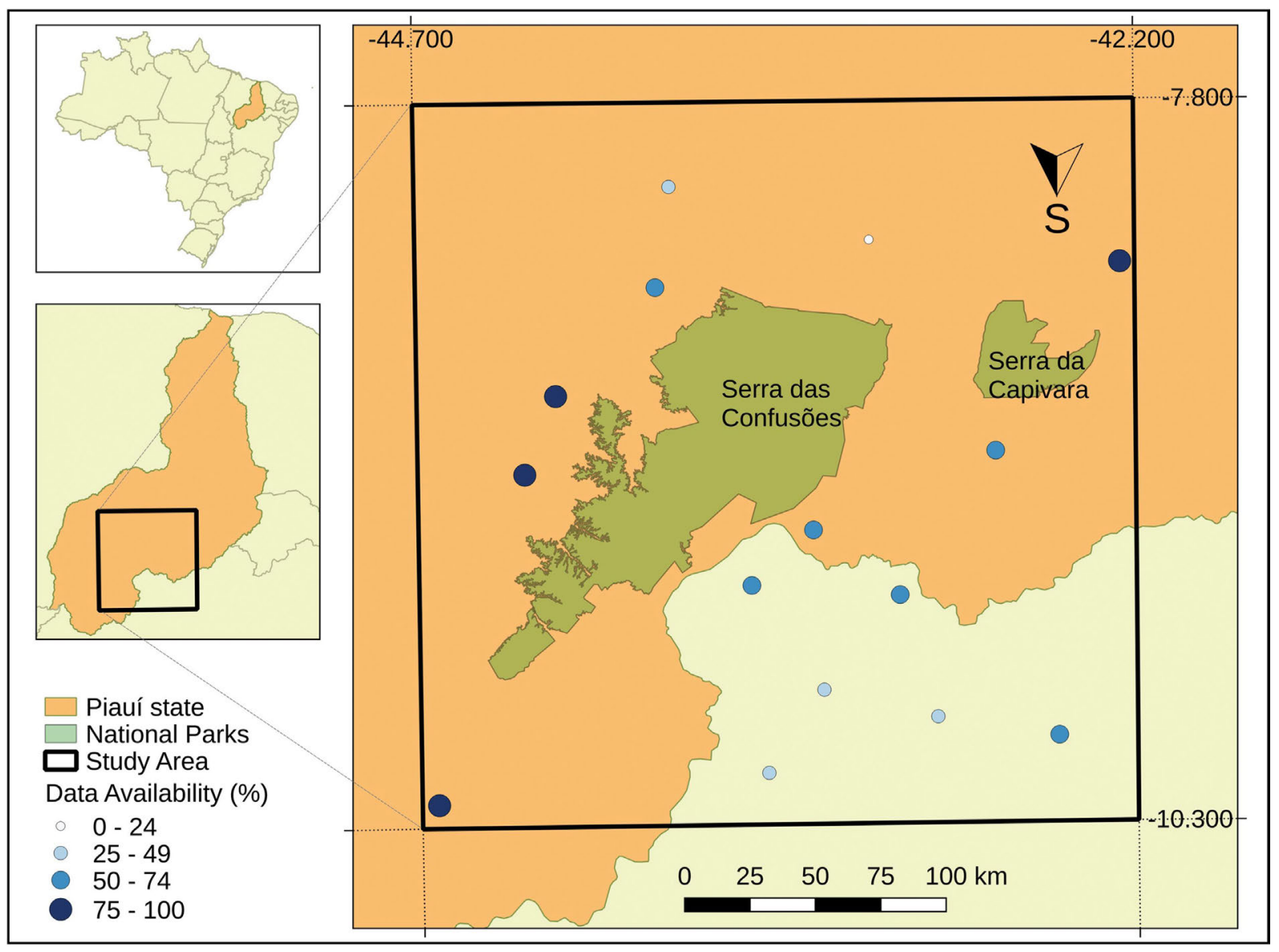

Figure 1 - (Color online) Study area represented by a square of $2.5^{\circ} \times 2.5^{\circ}$ that includes Serra da Capivara and Serra das Confusões National Parks (green), state of Piauí, NEB. Meteorological stations are depicted by (blue) dots, their sizes represent the availability of data in the period under consideration (July 1983 to June 2018). 
Serra da Capivara National Park protects approximately 134 thousand ha of Caatinga vegetation and archaeological sites, including rock paintings and the earliest evidence of human occupation in South America (Lahaye et al., 2013). Serra das Confusões National Park is the biggest conservation unit of Caatinga vegetation with 834 thousand ha, preserving not only Caatinga ecosystems but also the Caatinga-Cerrado ecotone (IBAMA, 2003). It also presents some relicts of Atlantic forest in the deep canyons, rock outcrops, caves, rock paintings and archaeological sites. Both parks were declared as areas of extreme priority for the conservation of the biodiversity of the Caatinga (Tabarelli and Silva, 2003), which presents a high level of endemism of succulents and woody species (Prado, 2003). Even when an ecological corridor between the parks was created in 2005 , it is crossed by a paved road without safe passage for wildlife, and there exist several settlements with practices such as livestock rearing and family agriculture.

Most of the study area (70.7\%) belongs to the tropical with dry winter climate (Aw), according to Köppen's climate classification. The Aw climate presents in Brazil a west to east humidity gradient, belonging our study area to the west region which is the driest one within that climate, and limiting with the dry semiarid with low latitude and altitude climate (BSh) to which the remaining $29.3 \%$ of the area belongs to (Alvares et al., 2013).

\subsection{Rainfall data}

We worked with daily rainfall data from the Brazilian National Institute of Meteorology (INMET acronym in Portuguese) (INMET, 2018) and the National Water Agency of Brazil (ANA acronym in Portuguese) (ANA, 2018). All meteorological stations within the study area with available data in the period of July 1983 - June 2018 were considered (see Fig. 1). This 35-year long period exceeds the time period used in climatology to define normals ( 30 years).

We organized all data in the so-called climatological years, beginning on July 1 of each year and ending on June 30 of the next year, that is, starting on the dry period in order to include just one complete rainy season by year. For each day, we averaged the daily rainfall over all available stations. Monthly averages for the study area, as well as annual averages, were constructed from this previous average over stations. In this way, availability of daily data for the complete period was guaranteed even when the data of individual stations is not complete for the whole period. Data availability for each station can be seen in Fig. 1. For comments about the quality of the data by year see Table S1 and Table S2.

\subsection{Identification of onset and end of rainy season}

The onset and end of the rainy season for each climatological year was established following the methodo- logy of Liebmann et al. (2007). Thus, if $R(j)$ is the daily rainfall on day $j$ for our study area and $\bar{R}$ is its annual average, a quantity called anomalous accumulation, $A(j)$, is defined in the following way:

$$
A(j)=\sum_{i=1}^{j}(R(i)-\bar{R})
$$

where day 1 is taken to be July 1 (in the dry period). Thus, the onset of the rainy season of a given climatological year will be the day after that for which $A(j)$ reaches its minimum value. In a similar way, the end of the rainy season corresponds to the day in which $A(j)$ reaches its maximum value. The rainy season length is calculated as the difference (in days) between the onset and the end. The rain rate is the average of the daily rainfall within the dates corresponding to the rainy season.

\subsection{Dry season characterization}

The dry seasons are the time periods between those of the rainy seasons. Thus, it is possible to identify the beginning and end of each dry season from the dates corresponding to the previous and posterior rainy seasons.

\subsubsection{Early, middle and late dry season}

Transitions from rainy to dry season are not always sharp, and the same is true the other way around. We identified three possible stages within each dry season following Alves and Pérez-Cabello (2017). First, we searched for the longest period of consecutive days with daily rainfall lower than $5 \mathrm{~mm}$, and called it middle dry season. In this portion of the dry season, rainfall is in its minimum expression. Thus, length of the middle dry season can be though as a measure of the severity of the dry season. This stage is usually preceded by a transition period from the previous rainy season with intermediate level of rainfall (early dry season), and followed by another transition period towards the next rainy season (late dry season). These transition periods are absent in some years that present sharp beginning and/or end of rainfall.

\subsection{Data analysis}

We report averages and standard deviations (not standard errors) because we are interested in the characterization of the central tendency and interannual variability of the quantities. Long-term trend in annual rainfall was evaluated with a linear regression as a function of time. Linear regressions were also used to analyze the long-term trends of the following quantities: onset date, end date, length, and rain rate of rainy season, length of dry season and length of middle dry season. Seasonality was established by means of the average of monthly rainfall over the 35-year long period, and also by calculating the 3-month average of monthly rainfall. After rainy season onset and end dates were calculated for the complete 
period, the seasonality was re-evaluated as the proportion of annual rainfall that lies within the rainy season. That accumulated rainfall from onset to end of rainy season is called seasonal rainfall, and its relations with rainy season features (onset and end dates, and length) were evaluated using Pearson correlations. Also, Pearson correlation was used to evaluate if dry season length is more related to previous or posterior rainy season length. Autocorrelation of dry season length was calculated to test if there exists some periodicity in the duration of the dry seasons. All calculation were performed in the $\mathrm{R}$ software environment (version 3.4.4, R core Team, 2018) and results were considered significant for $P<0.05$.

\section{Results and Discussion}

\subsection{Trend in annual rainfall}

The annual rainfall for each climatological year from July 1983 to June 2018 can be seen in Fig. 2. It averages $749 \pm 140 \mathrm{~mm}$ and presents a significant decreasing tendency of $7 \pm 2 \mathrm{~mm} /$ year as it turns out from the linear regression that was fitted $\left(P=0.0019, R^{2}=0.2576\right)$. This is compatible with the slight rainfall decrease observed in several stations of NEB (da Silva, 2004). The negative tendency observed in annual rainfall could worsen in the future, since climate change scenarios indicate that the semiarid part of NEB will present rainfall deficit and increased aridity (Marengo and Bernasconi, 2015; Marengo et al., 2017; Vieira et al., 2015).

The minimum annual rainfall occurred in the climatological year 2011-2012 and was just $433 \mathrm{~mm}$; on the opposite extreme, annual rainfall reached $1024 \mathrm{~mm}$ on the exceptionally wet climatological year 1985-1986. This very high interannual variability for rainfall was before indicated for NEB (Correia Filho et al., 2019; Lyra et al.,

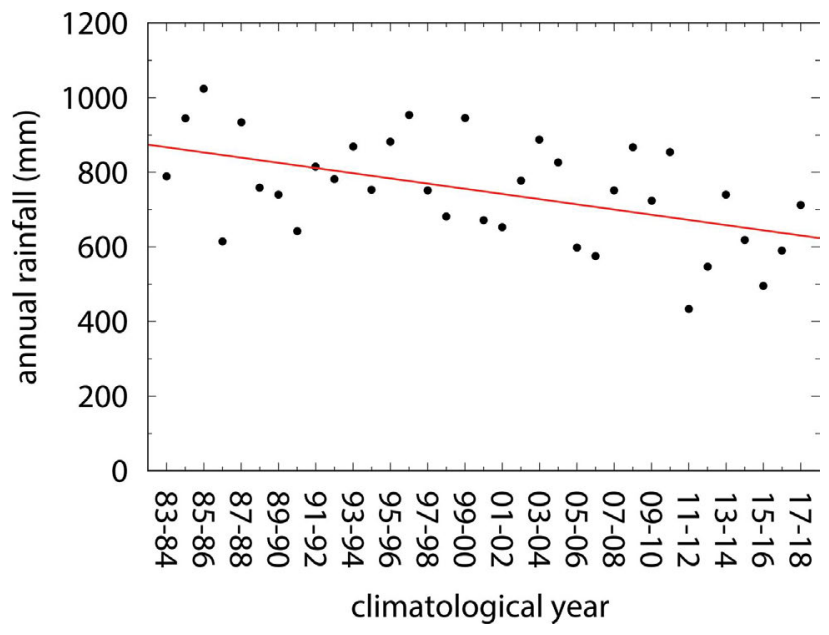

Figure 2 - Annual rainfall for the climatological years between July 1983 and June 2018 and its linear trend $(-7 \pm 2 \mathrm{~mm} /$ year).
2017) and is also typical in other semiarid regions of the world, like the Sahel and northeastern Africa (Nobre and Molion, 1988).

\subsection{Monthly rainfall}

The interval between November and April concentrates $90 \%$ of the annual rainfall, and that percentage climbs up to almost $96 \%$ if we also include October, see Fig. 3. Oppositely, averaged monthly rainfall is below $8 \mathrm{~mm}$ for the very dry period extending from June to September and reaches only $22 \mathrm{~mm}$ in May. The interannual variability of monthly rainfall is very large, as can be seen by the error bars in Fig. 3 that represent standard deviations.

Monthly rainfall peaks both in January and March, with a 3-month accumulated rainfall reaching a maximum during January-February-March (JFM), as can also be seen in Fig. 3. This double peak of monthly rainfall has also been reported for other regions like central and coastal parts of the state of Bahia that present a maximum in December and a secondary maximum in March (Nobre and Molion, 1988). Instead, in the northern part of NEB (near Fortaleza city) rainfall monthly maximum occurs during March and April, coastal areas in the eastern part (near Recife city) receive its maximum during May and July, and the southern and southwestern, in December (Hastenrath, 2012; Marengo and Bernasconi, 2015; Nobre and Molion, 1988).

\subsection{Rainy season characteristics}

Daily rainfalls and the corresponding anomalous accumulation, as calculated for each climatological year from 1983-1984 until 2017-2018, are shown in Figs. 4 and 5. From those calculations we obtained the dates of onset, end, and length of the rainy seasons that can be seen in Table S3 and Table S4.

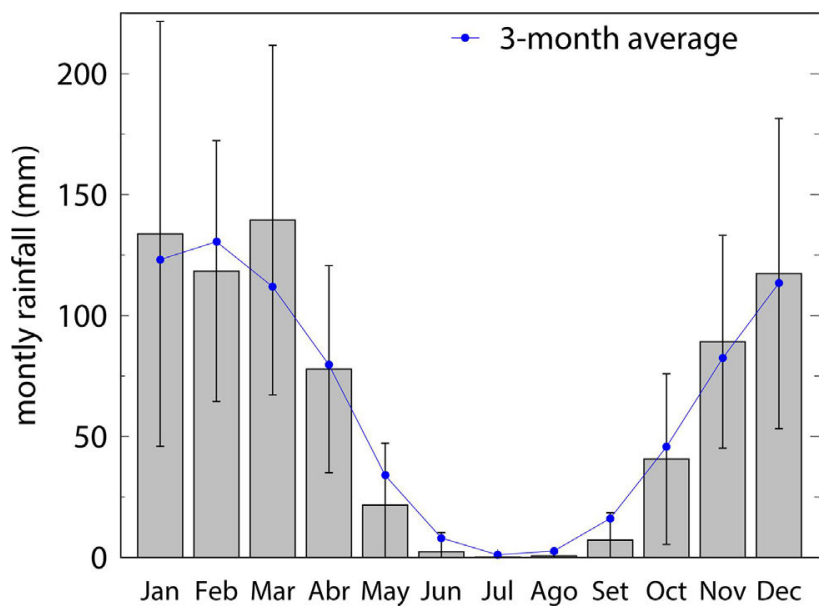

Figure 3 - Monthly rainfall averaged over the period from July 1983 to June 2018. Error bars represent standard deviations. Three-month average centered at each month is also shown. 
(a) $1983-1984$

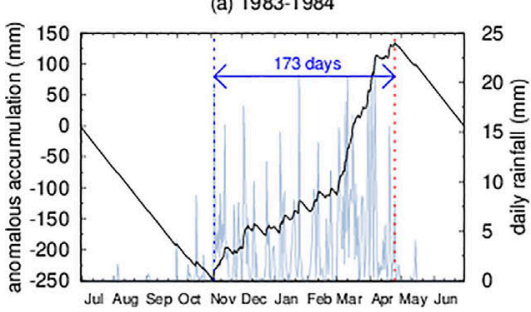

(d) $1986-1987$

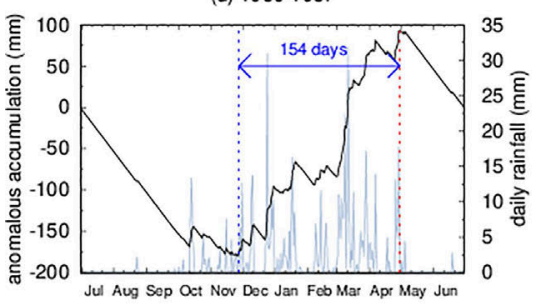

(g) $1989-1990$

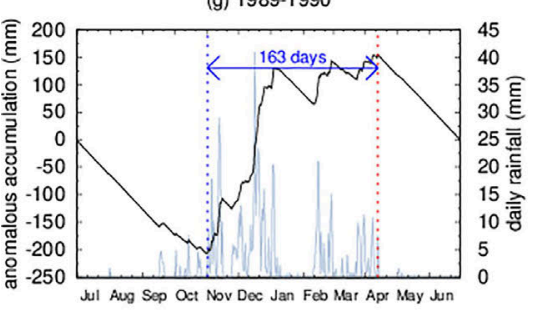

(j) 1992-1993

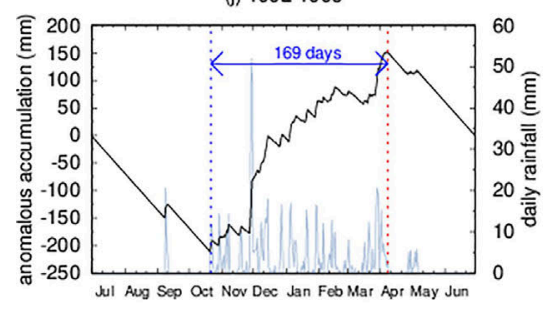

(m) 1995-1996

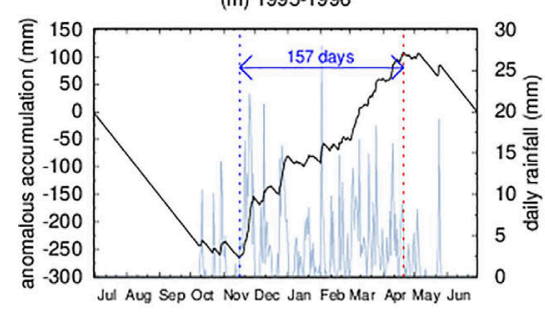

(p) 1998-1999

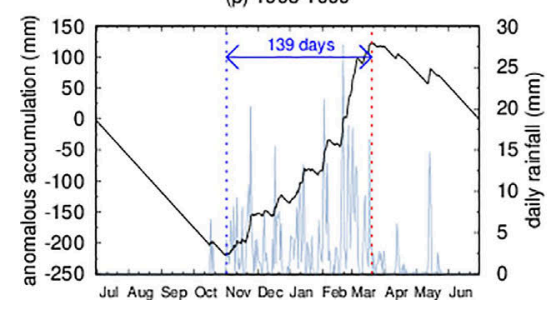

(b) 1984-1985

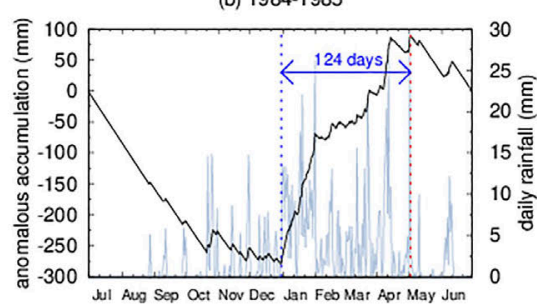

(e) $1987-1988$

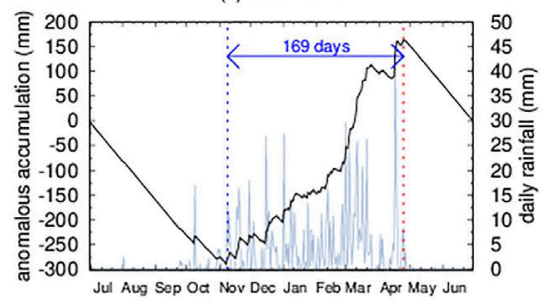

(h) 1990-1991

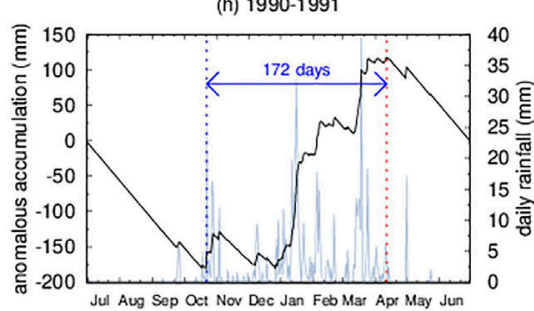

(k) 1993-1994

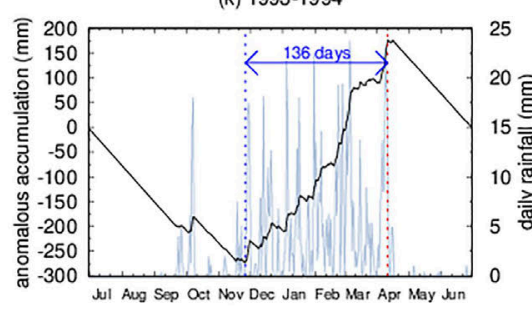

(n) 1996-1997

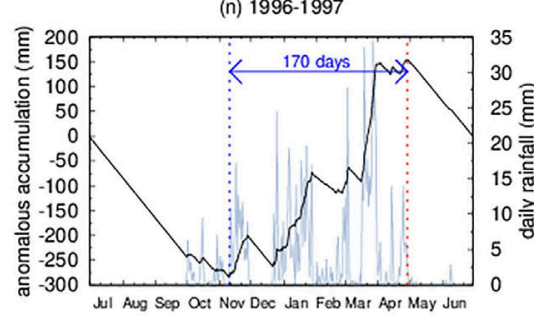

(q) $1999-2000$

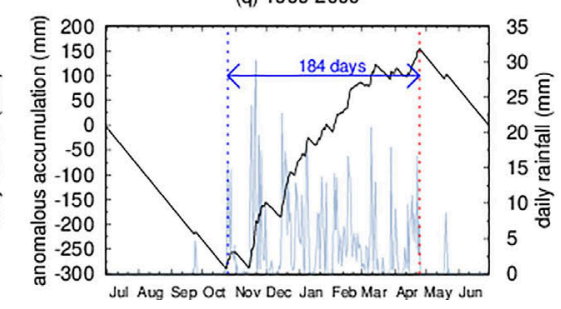

(c) $1985-1986$

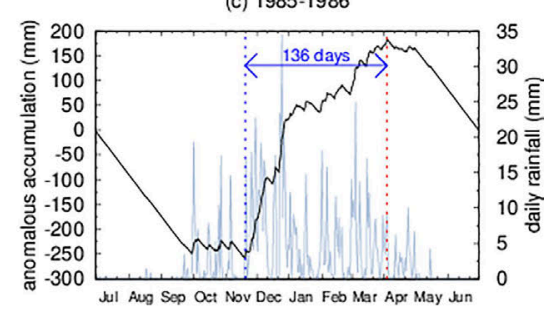

(f) $1988-1989$

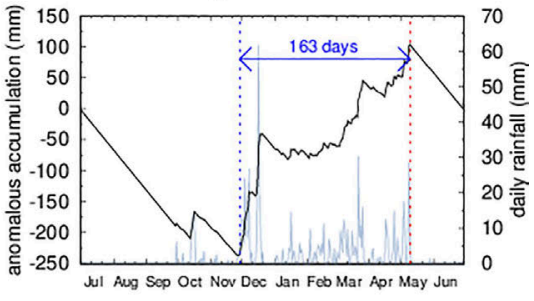

(i) 1991-1992

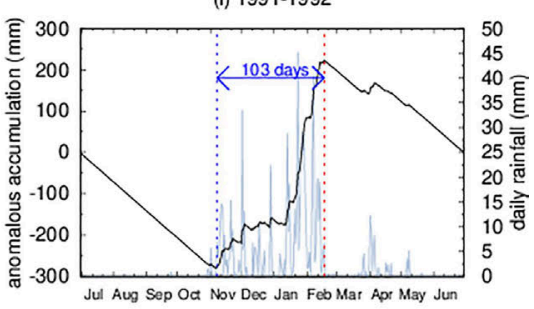

(l) 1994-1995

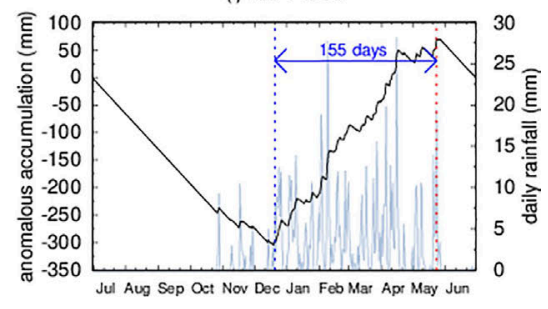

(o) $1997-1998$

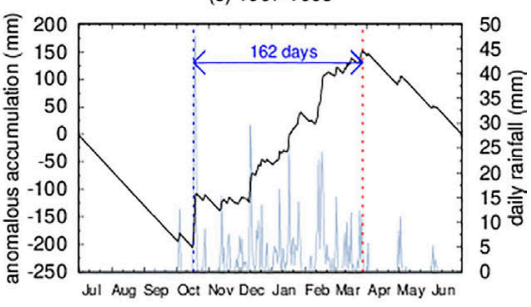

(r) 2000-2001

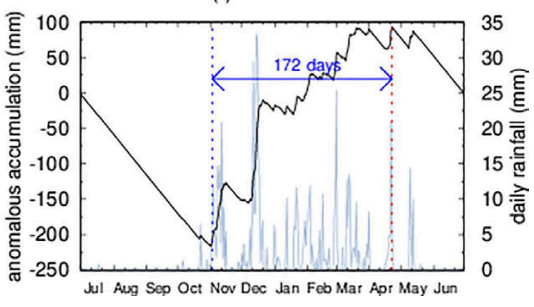

Figure 4 - (Color online) Daily rainfall and anomalous accumulation for each climatological year from July 1983 to June 2001. Onset (left blue dashed vertical line), end (right red dashed vertical line) and length (in days) of the rainy season are shown for each plot.

No significant tendency was found by fitting a linear regression as a function of time for onset date $(P=0.1805$, $\left.R^{2}=0.0536\right)$, end date $\left(P=0.2866, R^{2}=0.0343\right)$ or rainy season length $\left(P=0.9839, R^{2}<00001\right)$. Nevertheless, the three quantities greatly varied from year to year, as can be seen in Fig. 6. The average beginning of the rainy season 
(a) 2001-2002

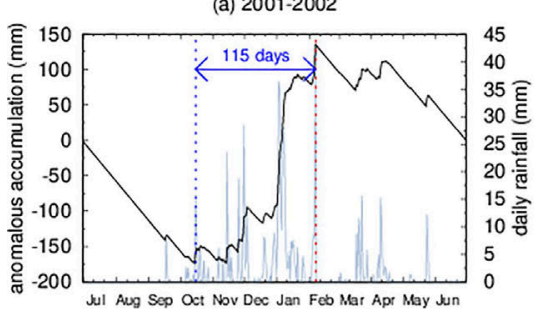

(d) 2004-2005

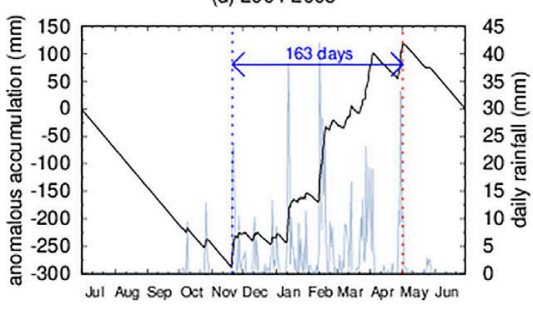

(g) 2007-2008

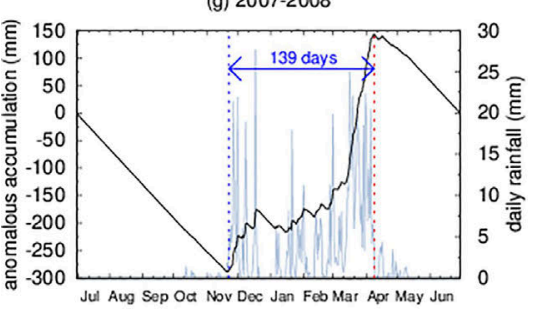

(j) 2010-2011

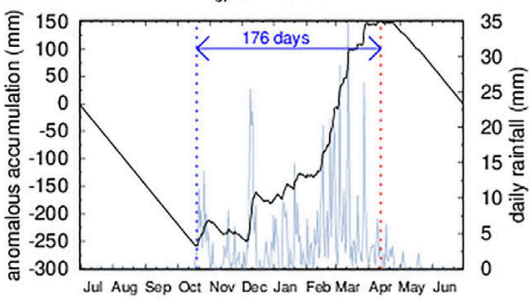

(m) 2013-2014

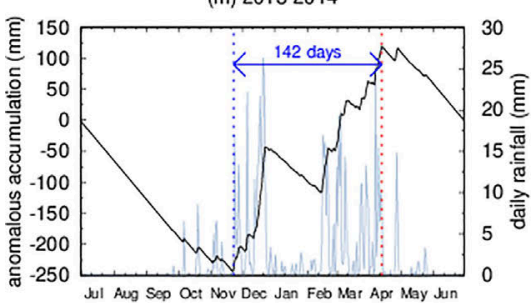

(p) 2016-2017

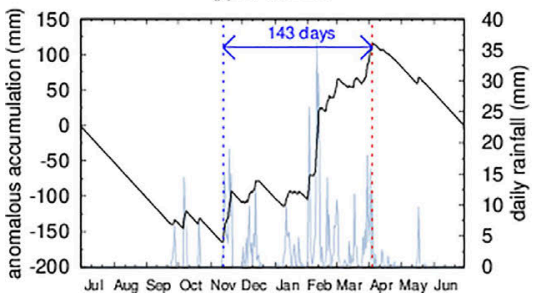

(b) 2002-2003

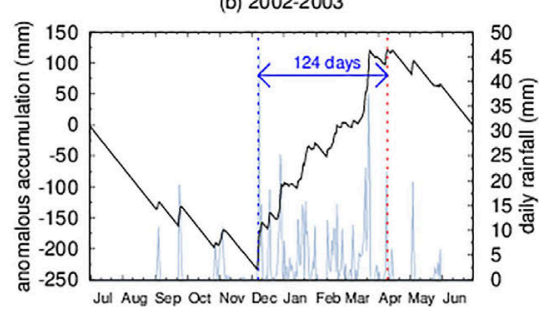

(e) $2005-2006$

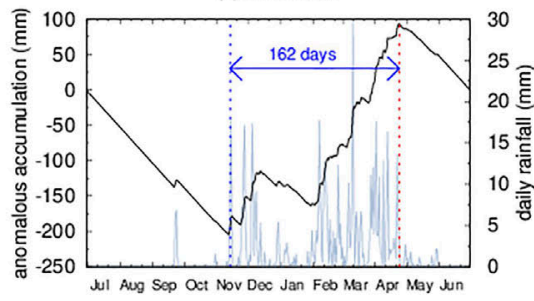

(h) 2008-2009

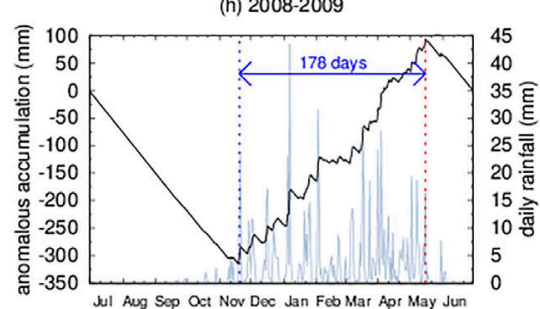

(k) 2011-2012

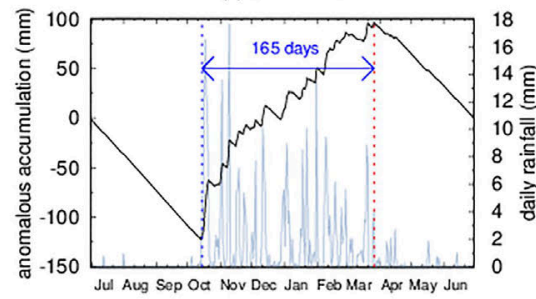

(n) 2014-2015

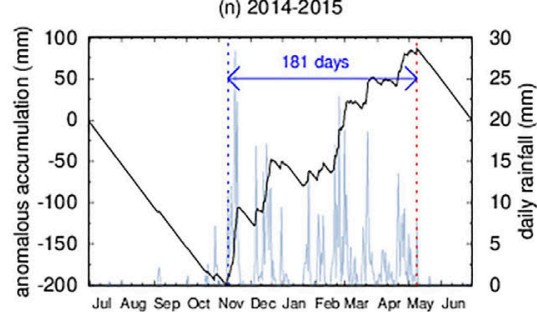

(q) 2017-2018

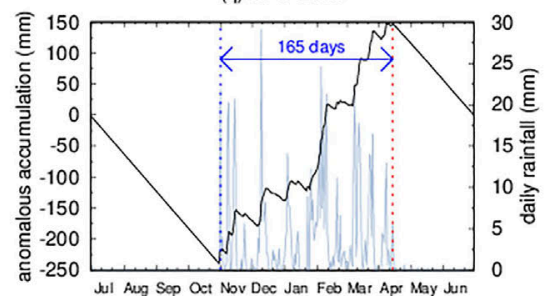

Figure 5 - (Color online) Daily rainfall and anomalous accumulation for each climatological year from July 2001 to June 2018 . Onset (left blue dashed vertical line), end (right red dashed vertical line) and length (in days) of the rainy season are shown for each plot.

is November, 11. The variability of its onset, quantified as the standard deviation, is 20 days. In the same way, the average date for the end is April, 11, with a variability of
25 days. A larger variability on the time of end as compared to onset is common over most regions of the world according to Janowiak and Xie (2003). On a 21-year 

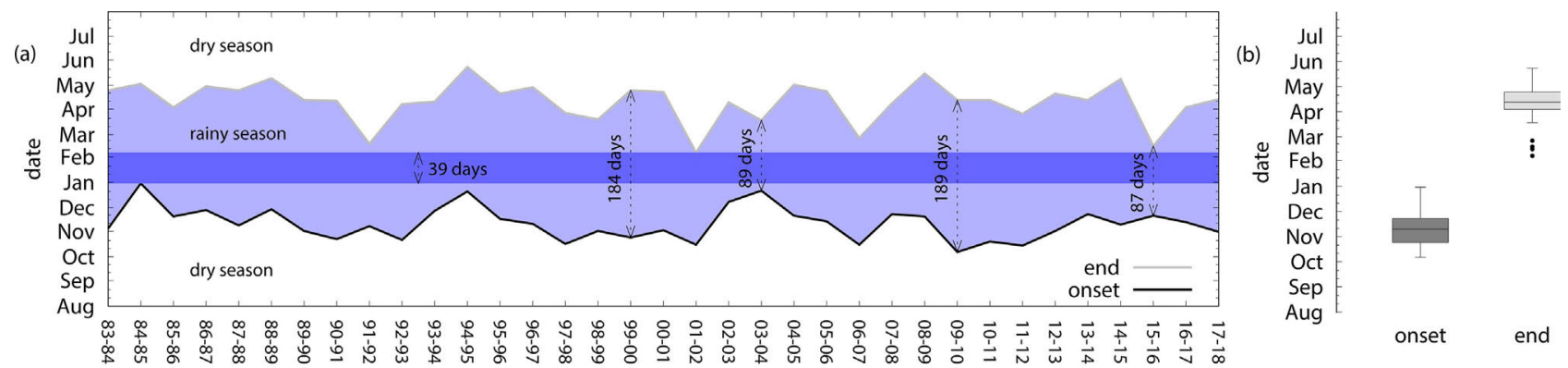

climatological year

Figure 6 - (Color online) (a) Rainy season interannual variability between July 1983 and June 2018. The lower (black) line represents the onset dates and the upper (gray) line, the end dates of the rainy seasons. Thus, the (light-blue shadowed) area between both curves represents the rainy season for the whole period. The vertical length between the curves represents the rainy season length for each climatological year. The two longest and the two shortest rainy seasons are identified. The darkest central shadow (blue rectangle) represents those dates that are always within the rainy season. See main text for more details. (b) Boxplot of onset and end of the rainy season. Atypical values (outliers) are shown as black dots.

study, the lowest variability with regard to rainy season onset was found over China and southeast Asia with 10 days or less, and the highest in the Austral-Asian domain with 20-30 days; while the highest variation on rainy season end (20-40 days) was observed over North America and the Austral-Asian region, and the lowest (1020 days), over tropical Africa, continental India, and the western portion of southeast Asia (Janowiak and Xie, 2003). Thus, the variability of the onset of the rainy season in our study area is close to the highest while that of the end, being 5 days longer ( $25 \%$ longer), is among the intermediate values.

The average of the rainy season length over the complete period is $152 \pm 26$ days. The longest rainy season was in 2009-2010, when it lasted for 189 days, while the second largest, with 184 days, was in 1999-2000. On the opposite extreme, the shortest rainy season was on climatological year 2015-2016 with just 87 days, and the second shortest, with 89 days, was in 2003-2004. If we compare the longest rainy season with the shortest one, the 102 days of difference represent almost $67 \%$ of the average rainy season length for the period. This great variation on rainy season length, and thus of the period in which rainfall is expected consistently, is one of the factors of socio-economic vulnerability of rural populations in NEB, affecting specially the rainfed crops of family agriculture, and also the availability of pastures for livestock feed and the storage of water for human consumption (de Andrade et al., 2016; IPCC, 2014). In Fig. 6(a), the two longest and the two shortest rainy seasons are identified, as well as the interval from December 31 to February 02, that lies always in the rainy season for the whole period from 1983 to 2018. This 39-days long interval is defined by the latest onset (December 31, corresponding to year 1984) and the earliest end (February 2, year 2002) of the rainy season.

Rain rate for each climatological year can also be seen in Table S3 and Table S4. It presents a marginally significant tendency of $-0.03 \pm 0.02(\mathrm{~mm} /$ day $) /$ year
$\left(P=0.0648, R^{2}=0.0996\right)$. This decreasing tendency is clear in Fig. 7, but its statistical significance is somehow masked by two atypical values corresponding to years 1991-1992 and 2003-2004, that are easily identified in the figure. Checking its daily rainfalls and the corresponding anomalous accumulation it is clear that on the climatological year 1991-1992 rainfall was high and very consistent over the complete rainy period (Fig. 4(i)). Instead, on climatological year 2003-2004 there were some rainfalls before the identified onset that were followed by a dry spell of almost 20 days (Fig. 5(c)). There, the anomalous accumulation takes values very close to the absolute minimum. If onset were defined associated to that secondary minimum (November, 01), rain rate would be $5.71 \mathrm{~mm} /$ year (not atypical anymore) instead of $7.69 \mathrm{~mm} /$ year and the linear regression for the rain rate would have the same slope $-0.03 \pm 0.01(\mathrm{~mm} /$ day $) /$ year with significant results $P=0.0251, R^{2}=0.1430$. Thus, rain rate presents a decreasing trend, which means that the

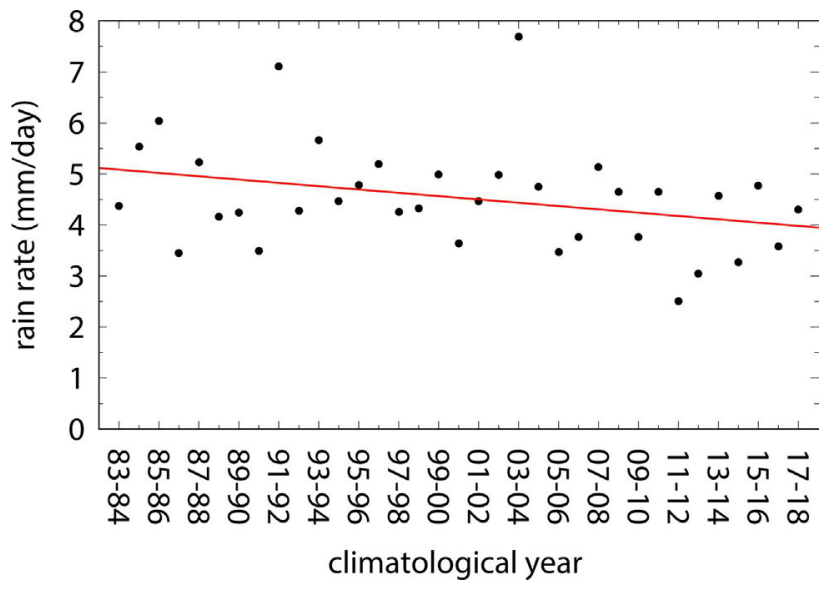

Figure 7 - Rain rate for the climatological years between July 1983 and June 2018 and its linear trend $(-0.03 \pm 0.02(\mathrm{~mm} /$ day $)$ (year). 
average of daily rainfall during the rainy season is lowering approximately $0.3 \mathrm{~mm} /$ day per decade.

\subsubsection{Rainy seasons features and seasonal rainfall}

The seasonal rainfall is the accumulated rainfall from onset to end of each rainy season and can be calculated from the obtained dates and the daily rainfall series. In the tropics and subtropics, the amount of rainfall during the rainy season is substantial relative to annual rainfall, contributing between $60 \%$ and $80 \%$ (Janowiak and Xie, 2003). For our study area, we found that seasonal rainfall represents on average $90 \%$ of the annual rainfall, which reveals the strong seasonality of the region.

Surprisingly, seasonal rainfall is uncorrelated with onset date $(r=0.0968, P=0.5798)$, and presents weak correlations with end date $(r=0.4359, P=0.0088)$, and rainy season length $(r=0.3416, P=0.0446)$. These unexpected results were also found in the Amazon basin, where Marengo et al. (2001) found little correlation between seasonal rainfall and rainy season length, with r-values below 0.35 in most regions. This was somewhat confirmed by a global-scale study by Janowiak and Xie (2003), that also found weak correlations between seasonal rainfall and rainy season length. They also found weak correlations between onset/end date for rainy season and seasonal rainfall.

\subsection{Dry season characteristics}

The average length of the dry season is $214 \pm 34$ days. It is 1.41 times larger than the mean length of the rainy season (152 \pm 26 days). No significant tendency was found by fitting a linear regression as a function of time for dry season length $\left(P=0.8316, R^{2}=0.0014\right)$.

The longest dry season was in 2002 and lasted 303 days, and the second longest was in 2016 and lasted 271 days. Instead, the year 2009 presented the shortest dry season, lasting 143 days, and 2017, the second shortest, with 165 days. The latest beginning of the dry season is May 25 (corresponding to the year 1995) and its earliest end is October 06 (year 2009). Thus, the 135day interval between those dates lies always within the dry season for the whole period under consideration (1983-2018).

The three longest dry seasons (2002, 2007, and 2016) are associated to early endings of the previous rainy season. These early endings appear as atypical values of the distribution of rainy season end dates, and can be seen as outliers in the boxplot of Fig. 6(b). Four outliers were identified and all of them represent early endings of the rainy season, corresponding to climatological years 19911992, 2001-2002, 2006-2007 and 2015-2016. No atypical values were identified as late endings and the distribution of onset dates present no atypical values.
Since the dry season is defined from the dates of the previous and posterior rainy seasons, the lengths of dry and rainy seasons are clearly not independent. In order to asses if dry season length is more related to the previous or posterior rainy season, we calculated the Pearson correlations for the two cases. The correlation was significant between dry season length and previous rainy season length $(r=-0.6722, P<0.0001)$ but it was not with the posterior one $(r=-0.2736, P=0.1174)$. This suggests that the length of the dry season is more regulated by the end date of the rainy period than by its onset date.

The autocorrelation of the dry season length can be seen in Fig. 8. It presents a significant negative value for a time lag of 7 years (consistently, the second largest modulus is positive for a time lag of 14 years). Thus, a short dry season could be expected seven years after a long one. And, in the same way, seven years after a long dry season, a short one could be expected. This 14-years long periodicity resemble that of 13 years found by Kane (1997) on long-term (130-years) series of rainfall in Fortaleza (coastal area on NEB).

\subsubsection{Severity of the dry season}

Transitions from the rainy to the dry season can be sharp: $38 \%$ of the years under consideration presented no early dry season. That is, 13 of 34 years presented the longest dry period at the very beginning of the dry season. In a similar way, 10 of 34 years $(29 \%)$ presented no late dry season, which means that the driest period was immediately followed by the next rainy season without a transition period. Most of the years that presented no late dry season (7 of 10, 70\%) were consecutive years from 2006 to 2012. The dry seasons of the years 2006, 2008, 2012, and 2015 were particularly dry with no single day with rainfall above $5 \mathrm{~mm}$, therefore those years had only middle dry season with neither early nor late dry seasons.

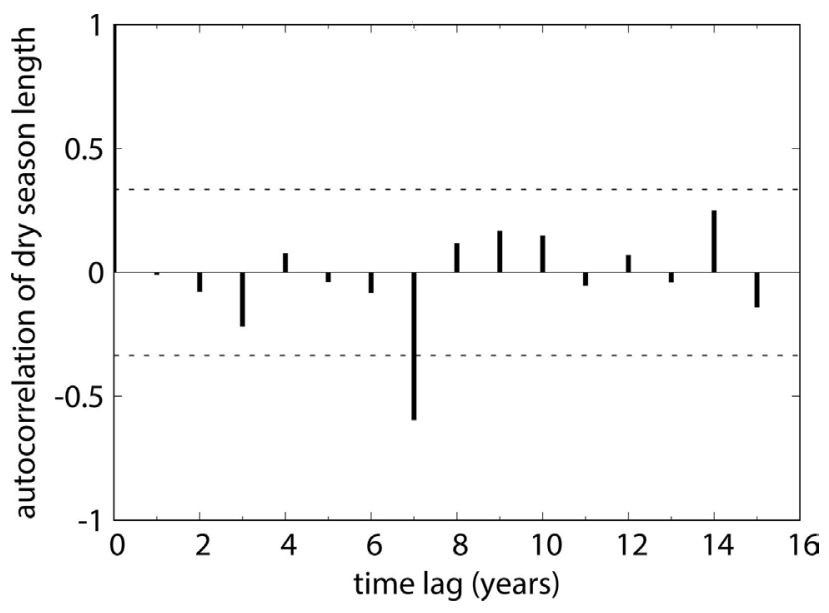

Figure 8 - Autocorrelation function of dry season length. Dashed lines represent the 0.95 confident interval. 
The early dry season has an average length of $24 \pm$ 27 days, the middle dry season of $158 \pm 31$ days, and the late dry season of $31 \pm 31$ days. Thus, dry season in our study area is mainly composed by a long very dry period at the middle with short transition periods that are absent in many of the years.

Although the years 2002 and 2016 had the two longest dry seasons, none of them presented the longest middle dry season. Years 2007 and 2008 are both at the top of that list, with 224 consecutive days of rainfalls under $5 \mathrm{~mm}$, followed by 2012 (219 days), 1994 (200 days) and 2015 (195 days). Longer middle dry seasons seems to be more common in recent years. In fact, a linear regression fit of middle dry season length presented an increase with time of $1.2 \pm 0.5$ days/year $\left(P=0.0240, R^{2}=0.1492\right)$ for the 34 -year-long period considered. This result is in accordance with the increase in consecutive dry days that was predicted for NEB as a consequence of climate change (IPCC, 2012; Marengo et al., 2017). Consecutive dry days (CDD), that is, the maximum number of consecutive days in a year with daily rainfall under some threshold, has been used as a drought indicator (Frich et al., 2002; IPCC, 2012; Marengo et al., 2017). Length of middle dry season, as used here, is equivalent to a CDD index with a $5 \mathrm{~mm} /$ day threshold.

Other thresholds has been considered in the literature, the more widely used is $1 \mathrm{~mm} /$ day (Frich et al., 2002; Guerreiro et al., 2013; IPCC, 2012). de Andrade et al. (2016) adopted a threshold of $2 \mathrm{~mm} /$ day on a study performed in NEB, following results from Fernandes et al. (2015) that showed that cowpea (Vigna unguiculata (L.) Walp.) is able to maintain transpiration and photosynthetic rates with around $2 \mathrm{~mm}$ of daily rainfall. This crop is widely produced under rainfed systems in NEB, being of extreme importance for family agriculture in the region. Analyzing our data again with these threshold values for the CDD, we found the same tendency as with $5 \mathrm{~mm} /$ day. That is, a slight statistically-significant increase in the number of CDD: for $2 \mathrm{~mm} /$ day, it is $1.2 \pm 0.5$ days/year $\left(P=0.0349, R^{2}=0.1317\right)$, and for $1 \mathrm{~mm} /$ day, it is $1.1 \pm$ 0.5 days/year $\left(P=0.0393, R^{2}=0.1261\right)$. Therefore, we can say that droughts are becoming more severe.

The dates of beginning, end and length of the dry season, including those of its three stages: early, middle and late dry season are detailed in Table S3 and Table S4.

\subsubsection{Comparison with a savanna enclave in Brazilian Amazon}

Alves and Pérez-Cabello (2017), analyzing a shorter time period that covers from 2000 to 2016 on a savanna enclave of the Brazilian Amazon, found a dry season length of $163 \pm 9$ days, which is 1.31 times shorter that the dry season of our study area. The early, middle and late dry seasons lengths that they found were $78 \pm 4$ days, $54 \pm$ 8 days, and $29 \pm 5$ days, respectively. That is qualitatively and quantitatively different from ours results. In first place, we found a dry season with a long middle period preceded and followed from short transitions, whereas they found well-defined transition periods of comparable length with the middle dry season. In fact, the early dry season is longer that middle dry season. Comparing, the middle dry season of our study area is almost 3 times longer and presents a variation in its length 6.75 times larger. It is clear that, besides our study area being an ecotone between Caatinga and Cerrado (savanna), the dry season characteristics are very different of those found for the savanna enclave in the Amazon.

\subsection{Droughts in northeastern Brazil}

During the time period considered in this work, drought episodes in NEB have been reported in the years: 1986-87, 1992-1993, 1997-1998, 2001-2002, 2005, 2007, 2010 e 2012-2016 (Marengo et al., 2017, 2018). Being those of the years 1997-1998 and 2012-2015, the ones reported as the most severe in the period (Brito et al., 2018; Gutiérrez et al., 2014; Marengo et al., 2018; Rodrigues and McPhaden, 2014).

For our study area, the lowest annual rainfall was in 2011-2012 which initiated a period of seven consecutive years with annual rainfall under the average. This period coincides with the most severe drought reported for recent decades in NEB, extending from 2012 to 2015. Also, the dry seasons of 2012 and 2015 are two of the only four that presented only middle dry season, meaning that there was very little rainfall outside the rainy seasons of those years. Moreover, 2012 presented the third longest middle dry season (third largest number of CDD). Major droughts in NEB are usually related to El Niño, as those of 1986-1987, 1997-1998, 2005, 2010 and 2015 (Marengo et al., 2018) and are due to the northward displacement of the ITCZ (Hastenrath, 2012). But not all droughts in NEB are related to El Niño, the 2011-2012 drought was on a non-El Niño year. La Niña events are usually associated to wet periods in NEB due to a southward migration of the ITCZ, but an opposite SST gradient in the tropical Atlantic can happen when the cooling is concentrated in the central Pacific instead of the eastern Pacific, thus leading to a northward migration of the ITCZ and to drought in the NEB, that was the case of the 2011-2012 drought event (Rodrigues and McPhaden, 2014).

On the other hand, the drought of 1997-1998 was also considered severe in NEB but annual rainfall was near the average for our study area, and neither dry season nor middle dry season were particularly long. This results are consistent with those of Cunha et al. (2018) that analyzed spatial-temporal pattern of drought in NEB and found that despite 1997-1998 being a severe drought in $\mathrm{NEB}$, it was not so intense in our study area.

The three longest dry seasons (2002, 2007, and 2016) occurred during years that have been reported as 
presenting droughts in the region. Moreover, from the above listed 16 years with reported drought, 10 had annual rainfall below the average ( $62 \%$ of the cases), 9 presented a dry season longer than the average (56\%), and in 7 of those years the middle dry season was longer than the corresponding average length (44\%). All these features characterize the so-called meteorological drought that is associated to rainfall deficit. The impacts of meteorological droughts can be diminished (or enhanced) by appropriate (or inadequate) public policies (Few and Tebboth, 2018; Sandstrom and Juhola, 2017). Drought is a complex phenomena and its ecological and socioeconomic impacts are influenced by human activities in several ways. In first place, meteorological droughts are influenced by the climate variability caused by anthropogenic climate change. But, their impacts depend also on changes in the land use, irrigation, reservoir construction and water abstraction which can or can not lead to soil moisture drought or hydrological drought (Van Loon et al., 2016). Sometimes, also agricultural droughts are considered to quantify impacts on crop yields (Bachmair et al., 2016).

\subsection{Implications on fire regimes}

Here, we identified a reducing level of annual rainfall as a long-term linear trend for the region, as well as a significant increase on CDD. Both have been mentioned as mechanisms that increase fire frequency and extent at a global scale (Shlisky et al., 2007). The decrease in rainfall affects biomass production and, thus, the availability of fuels, indirectly controlling fire activity (Mayr et al., 2018). It also influences fuel moisture that limits the extension of fires (Alvarado et al., 2017; Argañaraz et al., 2018).

Also, the high variability on the timing and quality of rainy season presents itself as a threat in terms of fire vulnerability, with dry seasons extending for as much as 303 days, as was the case in 2002. We found great interannual variability on the total amount of rainfall, which ranged from as little as $433 \mathrm{~mm}$ to as much as $1024 \mathrm{~mm}$. This variability is also a threat in terms of fire vulnerability since a very wet year could be followed by a very dry one increasing the risk of fire because great biomass production on wet years remains available as fuel during posterior dry periods. In fact, a fire database is available for this region in which a multiple-year process was described to explain large extensions burned in the Capivara-Confuses Mosaic for particular years (Argibay et al., 2020). The multiple-year process consists of a combination of a year with above-average rainfall followed by a year with below-average rainfall as $2010-2011(854 \mathrm{~mm})$ and 2011-2012 (433 mm) leading to a fire season (2012) in which large extensions were burned (Argibay et al., 2020). Seasonally dry tropical forests, as Caatinga, present high rates of biomass production during the rainy season directly associated with the amount of rainfall (Martínez-
Ramos et al., 2018). Thus, the combination of years with abundant rainfall followed by dry years with low rainfall levels and extended dry season periods are particularly risky.

Other fire vulnerability identified for the region is the existence of very dry years without transition seasons from and to rainy seasons. This superimposes to the intrinsically extreme seasonal climate we found in which $90 \%$ of rainfall is concentrated on the rainy season, which makes the long dry period intrinsically fire prone. The subdivision of the dry season seems to be appropriate to describe the differences in moisture conditions that drive fire activity. The fire database constructed by Argibay et al. (2020) for the same study area shows that the season with larger extension burned is the middle dry season, followed by the late dry season. Early dry seasons are the ones with less extension burned. This could reflect the fact that vegetation, during this period, is still with moisture derived from rains, even when rainy season has finished. Thus, dry season classification we made here prove to be useful for understanding fire dynamics and could as well be useful in other regions to understand fire regimes.

\section{Summary and Conclusions}

We have constructed a long-term series of daily rainfall data by spatial averaging the available data of ground-based stations, that otherwise present incomplete series, for semiarid NEB. The region includes two fully protected areas that together constitute the largest conservation area of Caatinga, a seasonally dry tropical forest that occurs only in Brazil. Assembling and analyzing longterm data is necessary to study ecological processes, such as those of fire regimes and their alteration by climate change. From our analysis, it is clear that high interannual climatic variations are the norm in the region, and should be incorporated in decision-making processes, particularly in the management of the two protected lands included in the area.

Protected areas have a crucial role in preserving biodiversity, ecosystem and landscape in situ, but protected areas of Caatinga and its ecotone with Cerrado are still poorly investigated and in need for studies that may help management decisions. In this sense, any study in which seasonality represents an important factor could benefit from the characterization that we have made here, not only studies related to fire but also to any seasonal ecological process, for example studies about population dynamics or species phenology. Particularly, yearly dates for start and end of rainy and dry seasons based on ground-based daily rainfall observations could be used to made dynamical approaches to any process, accounting for the real interannual variations in the timing and quality of rainy season. Avoiding, in this way, the usual rigid approach of defining 
seasons by climate normals and ignoring what is, in fact, happening on the particular years of the study.

A strong seasonality was evidenced by the concentration of $90 \%$ of rainfalls found in the rainy season, which in average extends for 152 days. Onset date of rainy season, as well as its end date and length presented high interannual variability, which can be summarized upon the fact that only 39 days exclusively belonged to rainy season for the complete 35-year period of this study, from December 31 to February 02 . Note that this can be considered the only period with consistent rainfall and is barely longer than a month. As compared, 135 days (between 4 and 5 months) belonged always to the dry season, from May 25 to October 06 . The high interannual variability also characterizes the region in terms of annual and monthly rainfall.

As a long-term tendency, we have identified a significant decrease in annual rainfall. Also, we have showed that consecutive dry days presented a significant increasing linear tendency considering a threshold of $5 \mathrm{~mm}$ for daily rainfall, and also with thresholds of $2 \mathrm{~mm}$ and $1 \mathrm{~mm}$. That is, the number of consecutive dry days, very dry days and extremely dry days are all increasing. Thus, droughts are becoming more severe. Among the considered features of the rainy season, onset and end dates, and length of the rainy season presented no significant tendency. Instead, rain rate showed a significant decreasing trend. Thus, the decrease in annual rainfall would be associated to a diminishing rate of rainfall on the rainy season rather than a shorter rainy period or a change in its timing.

The complexity of the rainfall patterns are evidenced by the low correlation between seasonal rainfall and rainy season length. Seasonal rainfall presented a moderate correlation with end date of rainy season but it was uncorrelated with its onset date. This could mean that the end of rainy season is the most relevant feature to characterize the amount of rainfall, and years with poor rainfall would be mainly associated with early endings. This is reinforced by the negative correlation of dry season length with previous rainy season length but not with the posterior one, and by the fact that the atypical values found on onset and end dates distributions represent, all of them, early endings of rainy season.

Certain regularity can be attributed to dry season patterns, we have found a significant autocorrelation for the dry season length, with a periodicity of 14 years, which means that short and long dry seasons alternate separated by approximately 7 years.

\section{Acknowledgments}

This work was supported by the National Council for Scientific and Technological Development - CNPq, [grant number Proc 421178/2017-5]. JS received a fellowship from CNPq, and DSA a master's scholarship from PAEC/ OEA.

\section{References}

ALLEN, K.; DUPUY, J.M.; GEI, M.G.; HULSHOF, C.; MEDVIGY, D.; et al. Will seasonally dry tropical forests be sensitive or resistant to future changes in rainfall regimes? Environmental Research Letters, v. 12, n. 2, p. 023001, 2017.

ALVARADO, S.T.; FORNAZARI, T.; CÓSTOLA, A.; MORELLATO, L.P.C.; SILVA, T.S.F. Drivers of fire occurrence in a mountainous Brazilian cerrado savanna: Tracking long-term fire regimes using remote sensing. Ecological Indicators, v. 78, p. 270-281, 2017.

ALVARES, C.A.; STAPE, J.L.; SENTELHAS, P.C.; DE MORAES GONÇALVES, J.L.; SPAROVEK. G. Köppen's climate classification map for Brazil. Meteorologische Zeitschrift, v. 22, n. 6, p. 711-728, 2013.

ALVES, D.B.; PÉREZ-CABELLO, F. Multiple remote sensing data sources to assess spatio-temporal patterns of fire incidence over campos amazônicos savanna vegetation enclave (brazilian Amazon). Science of the Total Environment, v. 601-602, p. 142-158, 2017.

ANA (2018) https://www.snirh.gov.br/hidroweb/publico/medi coes_historicas_abas.jsf [Retrieved: October 29, 2018]

DE ANDRADE, E.M.; SENA, M.G.T.; DA SILVA, A.G.R.; PEREIRA, F.J.S.; LOPES, F.B. Uncertainties of the rainfall regime in a tropical semi-arid region: the case of the state of Ceará. Revista Agro@mbiente On-line, v. 10, n. 2, p. 88-95, 2016.

ARCHIBALD, S.; LEHMANN, C.E.R.; GOMEZ-DANS, J.L.; BRADSTOCK, R.A. Defining pyromes and global syndromes of fire regimes. Proceedings of the National Academy of Sciences, v. 110, p. 6442-6447, 2013.

ARGAÑARAZ, J.P.; LANDI, M.A.; SCAVUZZO, C.M.; BELLIS, L.M. Determining fuel moisture thresholds to assess wildfire hazard: a contribution to an operational early warning system. PloS One v. 13, n. 10, p. e0204889, 2018.

ARGIBAY, D.S.; SPARACINO, J.; ESPINDOLA, G.M. A longterm assessment of fire regimes in a Brazilian ecotone between seasonally dry tropical forests and savannah. Ecological Indicators, v. 113, p. 106151, 2020.

BARBOSA, H.A.; KUMAR, T.V.L.; PAREDES, F.; ELLIOTT, S.; AYUGA, J.G. Assessment of Caatinga response to drought using Meteosat-SEVIRI Normalized Difference Vegetation Index (2008 - 2016). ISPRS Journal of Photogrammetry and Remote Sensing, v. 148, p.235-252, 2019.

BACHMAIR, S.; STAHL, K.; COLLINS, K.; HANNAFORD, J.; ACREMAN, M.; et al. Drought indicators revisited: the need for a wider consideration of environment and society. WIREs Water, v. 3, n. 4, p. 516-536, 2016.

BOND, W.J.; KEELEY, J.E. Fire as a global herbivore: the ecology and evolution of flammable ecosystems. Trends in Ecology \& Evolution, v. 20, n. 7, p. 387-394, 2005.

BRITO, S.S.B.; CUNHA, A.P.M.A.; CUNNINGHAM, C.C.; ALVALÁ, R.C.; MARENGO, J.A.; et al. Frequency, duration and severity of drought in the Semiarid Northeast Bra- 
zil region. International Journal of Climatology, v. 38, n.2, p. 517-529, 2018.

CAMBERLIN, P.; MORON, V.; OKOOLA, R.; PHILIPPON, N.; GITAU, W. Components of rainy seasons' variability in Equatorial East Africa: onset, cessation, rainfall frequency and intensity. Theoretical and Applied Climatology, v. 98, n. 3, p. 237-249, 2009.

CLARKE, A.J. An Introduction to the Dynamics of El Niño and the Southern Oscillation. Elsevier, Oxford, UK, pp. 308, 2008.

COCHRANE, M.A. Fire science for rainforests. Nature, v. 421, n. 6926, p. 913-919, 2003.

COELHO, C.A.S.; CARDOSO, D.H.F.; FIRPO, M.A.F. Precipitation diagnostics of an exceptionally dry event in São Paulo, Brazil. Theoretical and Applied Climatology, v. 125, n. 3, p. 769-784, 2016.

CUNHA, A.P.M.A.; TOMASELLA, J.; RIBEIRO-NETO, G.G.; BROWN, M.; GARCIA. S.R.; et al. Changes in the spatialtemporal patterns of droughts in the Brazilian Northeast. Atmospheric Science Letters, v. 19, p. e855, 2018.

CORREIA FILHO, W.L.F.; DE OLIVEIRA-JNIOR, J.F.; DE BARROS, S.D.; DE BODAS TERASSI, P.M.; TEODORO, P.E.; et al. Rainfall variability in the Brazilian northeast biomes and their interactions with meteorological systems and ENSO via CHELSA product Big Earth Data, v. 3, n. 4, p. 315-337, 2019.

DEBORTOLI, N.S.; DUBREUIL, V.; HIROTA, M.; FILHO, S.R.; LINDOSO, D.P.; et al. Detecting deforestation impacts in southern Amazonia rainfall using rain gauges. International Journal of Climatology, v. 37, n. 6, p. 2889-2900, 2017.

DINERSTEIN, E.; OLSON, D.; JOSHI, A.; VYNNE, C.; BURGESS, N.D.; et al. An ecoregion-based approach to protecting half the terrestrial realm. BioScience, v. 67, n. 6, p. 534-545, 2017.

FERNANDES, F.B.P.; DE LACERDA, C.F.; DE ANDRADE, E.M.; NEVES, A.L.R.; DE SOUSA, C.H.C. Efeito de manejos do solo no déficit hídrico, trocas gasosas e rendimento do feijão-de-corda no semiárido. Revista Ciência Agronômica, v. 46, n. 3, p.506-515, 2015.

FEW, R.; TEBBOTH, M.G. Recognising the dynamics that surround drought impacts. Journal of Arid Environments, v. 157, p.113-115, 2018.

FRICH, P.; ALEXANDER, L.; DELLA-MARTA, P.; GLEASON, B.; HAYLOCK, M.; et al. Observed coherent changes in climatic extremes during the second half of the twentieth century. Climate Research, v. 19, n. 3, p. 193$212,2002$.

GUERREIRO, M.J.S.; MAIA DE ANDRADE, E.; ABREU, I.; LAJINHA, T. Long-term variation of precipitation indices in Ceará state, Northeast Brazil. International Journal of Climatology, v. 33, n. 14, p. 2929-2939, 2013.

GUTIÉRREZ, A.P.A.; ENGLE, N.L.; NYS, E.D.; MOLEJÓN, C.; MARTINS, E.S. Drought preparedness in Brazil. Weather and Climate Extremes, v. 3, p. 95-106, 2014.

HASTENRATH, S. Exploring the climate problems of Brazil's Nordeste: a review. Climatic Change, v. 112, n. 2, p. 243$251,2012$.
HOLDEN, Z.A.; SWANSON, A.; LUCE, C.H.; JOLLY, W.M.; MANETA, M.; et al. Decreasing fire season precipitation increased recent western US forest wildfire activity. Proceedings of the National Academy of Sciences, v. 115, n. 36, p. E8349-E8357, 2018.

HOREL, J.D.; HAHMANN, A.N.; GEISLER, J.E. An investigation of the annual cycle of convective activity over the tropical Americas. Journal of Climate, v. 2, n. 11, p.13881403, 1989.

IBAMA (2003) Plano de manejo do Parque Nacional da Serra das Confusões - PI. Instituto Brasileiro do Meio Ambiente e Recursos Naturais Renováveis - IBAMA. http://www.icmbio.gov.br/portal/images/stories/imgs-uni dades-coservacao/parna_serra_das_confusoes.pdf [Last access: March 20, 2019]

INMET (2018) https://www.inmet.gov.br/portal/index.php? r=bdmep/bdmep [Retrieved: September 10, 2018]

IPCC. Managing The Risks Of Extreme Events And Disasters To Advance Climate Change Adaptation. A special report of Working Groups I and II of the Intergovernmental Panel on Climate Change. FIELD, C.B, V. BARROS, T.F. STOCKER, D. QIN, D.J. DOKKEN, K.L. EBI, M.D. MASTRANDREA, K.J. MACH, G.-K. PLATTNER, S.K. ALLEN, M. TIGNOR, P.M. MIDGLEY (eds.). Cambridge: Cambridge University Press, 2012.

IPCC. Climate Change 2014: Impacts, Adaptation, and Vulnerability. Part B: Regional Aspects. Contribution of Working Group II to the Fifth Assessment Report of the Intergovernmental Panel on Climate Change. BARROS, V.R., C.B. FIELD, D.J. DOKKEN, M.D. MASTRANDREA, K.J. MACH, T.E. BILIR, M. CHATTERJEE, K.L. EBI, Y.O. ESTRADA, R.C. GENOVA, B. GIRMA, E.S. KISSEL, A.N. LEVY, S. MACCRACKEN, P.R. MASTRANDREA, L.L. WHITE (eds.). Cambridge: Cambridge University Press, 2014.

JANOWIAK, J.E., XIE, P. A global-scale examination of monsoon-related precipitation. Journal of Climate, v. 16, n. 24, p. 4121-4133, 2003

KANE, R.P. Prediction of droughts in North-East Brazil: Role of ENSO and use of periodicities. International Journal of Climatology, v. 17, n. 6, p. 655-665, 1997.

KOUSKY, V. Pentad outgoing longwave radiation climatology for the South American sector. Revista Brasileira de Meteorologia v. 3, n. 1, p. 217-231, 1988.

LAHAYE, C.; HERNANDEZ, M.; BOËDA, E.; FELICE, G.D.; GUIDON, N., et al. (2013) Human occupation in South America by 20,000 BC: the Toca da Tira Peia site, Piauí, Brazil. Journal of Archaeological Science, v. 40, n. 6, p. 2840-2847, 2013.

LEMOS, J.R.; RODAL, M.J.N. Fitossociologia do componente lenhoso de um trecho da vegetação de Caatinga no Parque Nacional Serra da Capivara, Piauí, Brasil. Acta Botanica Brasilica, v. 16, p. 23-42, 2002.

LIEBMANN, B.; MARENGO, J. (2001) Interannual variability of the rainy season and rainfall in the brazilian Amazon basin. Journal of Climate, v. 14, n. 22, p. 4308-4318, 2001.

LIEBMANN, B.; CAMARGO, S.J.; SETH, A.; MARENGO, J.A.; CARVALHO, L.M.V.; et al. Onset and end of the 
rainy season in South America in observations and the ECHAM 4.5 atmospheric general circulation model. Journal of Climate, v. 20, n. 10, p. 2037-2050, 2007.

LYRA, G.B.; OLIVEIRA-JÚNIOR, J.F.; GOIS, G.; CUNHAZERI, G.; ZERI, M. Rainfall variability over Alagoas under the influences of SST anomalies. Meteorology and Atmospheric Physics, v. 129, p. 157-171, 2017.

MARENGO, J.A.; BERNASCONI, M. Regional differences in aridity/drought conditions over Northeast Brazil: present state and future projections. Climatic Change, v.129, n. 1, p. 103-115, 2015.

MARENGO, J.A.; LIEBMANN, B.; KOUSKY, V.E.; FILIZOLA, N.P.; WAINER, I.C. Onset and end of the rainy season in the brazilian Amazon basin. Journal of Climate, v. 14, n. 5, p. 833-852, 2001.

MARENGO, J.A.; TORRES, R.R.; ALVES, L.M. Drought in Northeast Brazil-past, present, and future. Theoretical and Applied Climatology, v. 129, n. 3, p. 1189-1200, 2017.

Marengo, J.A.; Alves, L.M.; Alvala, R.C.; Cunha, A.P.; Brito, S.; et al. Climatic characteristics of the 2010-2016 drought in the semiarid Northeast Brazil region. Anais da Academia Brasileira de Ciências, v. 90, p. 1973-1985, 2018.

MARJUKI; VAN DER SCHRIER, G.; KLEIN TANK, A.M.G.; VAN DEN BESSELAAR, E.J.M.; NURHAYATI; et al. Observed trends and variability in climate indices relevant for crop yields in Southeast Asia. Journal of Climate, v. 29, n. 7, p. 2651-2669, 2016.

MARTÍNEZ-RAMOS, M.; BALVANERA, P.; VILLA, F.A.; MORA, F.; MAASS, J.M.; et al. Effects of long-term interannual rainfall variation on the dynamics of regenerative communities during the old-field succession of a neotropical dry forest. Forest Ecology and Management, v. 426, p. 91-100, 2018.

MARTINS, E.S.P.R.; COELHO, C.A.S.; HAARSMA, R.; OTTO, F.E.L.; KING, A.D.; et al. A Multimethod Attribution Analysis of the Prolonged Northeast Brazil Hydrometeorological Drought (2012-16). Bulletin of the American Meteorological Society, v. 99, n. 1, p. S65-S69, 2018.

MAYR, M.; VANSELOW, K.; SAMIMI, C. Fire regimes at the arid fringe: A 16-year remote sensing perspective (2000 2016) on the controls of fire activity in Namibia from spatial predictive models. Ecological Indicators, v. 91, p. 324337, 2018.

NOBRE, C.; MOLION, L. The climatology of droughts and drought prediction. In: The Impact of Climatic Variations on Agriculture, v. 2, Berlin: Springer, pp 305-323, 1988.

OLMOS, F. Serra Da Capivara National Park and the conservation of north-eastern Brazil's Caatinga. Oryx, v. 26, n. 3, p. 142-146, 1992.

PRADO, D. As caatingas da américa do sul. In: Ecologia e Conservação da Caatinga, Recife: Ed. Universitria da UFPE, pp. 3-73, 2003.

PRÅVĂLIE, R. Drylands extent and environmental issues. A global approach. Earth-Science Reviews, v. 161, p. 259278, 2016.

ROCKSTRÖM, J.; KARLBERG, L.; WANI, S.P.; BARRON, J.; HATIBU, N.; et al. Managing water in rainfed agriculture The need for a paradigm shift. Agricultural Water Management, v. 97, n. 4, p. 543-550, 2010.
RODRIGUES, R.R.; MCPHADEN, M.J. Why did the 2011 2012 La Niña cause a severe drought in the brazilian Northeast? Geophysical Research Letters, v. 41, n. 3, p. 1012-1018, 2014.

SANDSTROM, S.; JUHOLA, S. Continue to blame it on the rain? Conceptualization of drought and failure of food systems in the greater horn of Africa. Environmental Hazards v. 16, n. 1, p. 71-91, 2017.

SANTOS, M.G.; OLIVEIRA, M.T.; FIGUEIREDO, K.V.; FALCÃO, H.M.; ARRUDA, E.C.P.; et al. Caatinga, the brazilian dry tropical forest: can it tolerate climate changes? Theoretical and Experimental Plant Physiology, v. 26, n. 1, p. 83-99, 2014.

SHLISKY, A.; WAUGH, J.; GONZALEZ, P.; GONZALEZ, M; MANTA, M.; et al. Fire, Ecosystems and People: Threats and Strategies for Global Biodiversity Conservation. GFI Technical Report 2007-2, Arlington: The Nature Conservancy, 2007.

SHLISKY, A.; ALENCAR, A.A.; NOLASCO, M.M.; CURRAN, L.M. Overview: global fire regime conditions, threats, and opportunities for fire management in the tropics. In: Tropical Fire Ecology, Berlin: Springer, pp. 6583, 2009.

SIETZ, D.; UNTIED, B.; WALKENHORST, O; LÜDEKE, M.K.B.; MERTINS, G.; et al. Smallholder agriculture in Northeast Brazil: assessing heterogeneous human-environmental dynamics. Regional Environmental Change, v. 6, n. 3, p. 132-146, 2006.

DA SILVA, V.D.P.R. On climate variability in Northeast of Brazil. Journal of Arid Environments, v. 58, n. 4, p. 575-596, 2004.

SOMBROEK, W. Spatial and temporal patterns of Amazon rainfall. AMBIO: A Journal of the Human Environment, v. 30, n. 7, p. 388-396, 2001.

TABARELLI, M.; SILVA, J. Áreas e ações prioritárias para a conservação da biodiversidade da Caatinga. In: Ecologia e conservação da Caatinga, Recife: Ed. Universitária da UFPE, pp. 777-796, 2003.

VAN LOON, A.F.; GLEESON, T.; CLARK, J.; VAN DIJK, A.I.; STAHL, K.; et al. Drought in the anthropocene. Nature Geoscience, v. 9, n. 2, p. 89, 2016.

VIEIRA, R.M.S.P.; TOMASELLA, J.; ALVALÁ, R.C.S.; SESTINI, M.F.; AFFONSO, A.G.; et al. Identifying areas susceptible to desertification in the brazilian northeast. Solid Earth, v. 6, n. 1, p. 347-360, 2015.

YADAV, S.; LAL, R. Vulnerability of women to climate change in arid and semi-arid regions: The case of India and South Asia. Journal of Arid Environments, v. 149, p. 4-17, 2018.

\section{Supplementary Material}

Table S1 - Meteorological station locations and source of the corresponding data.

Table S2 - Minimum (MIN), maximum (MAX) and average (AVG) number of stations with available data for each climatological year under consideration. The average is calculated over each day of the climatological year and the associated standard deviation (STDEV) is also shown. 
Table S3 - Dates of onset and end of each rainy season for the period between July 1983 and June 2018, as calculated from the anomalous accumulation for each climatological year. The length in days and the rain rate of each rainy season are also shown.

Table S4 - Dates of beginning and end, length and rain rate of each dry season in the period between July 1983 and June
2018. The corresponding dates for early, middle, and late dry seasons are also shown, as well as their lengths in days.

License information: This is an open-access article distributed under the terms of the Creative Commons Attribution License (type CC-BY), which permits unrestricted use, distribution and reproduction in any medium, provided the original article is properly cited. 